\title{
Regression of Science Process Skills On Critical Thinking Skills In Two Junior High Schools In Jambi City
}

\author{
Darmaji $^{1}$, Astalini ${ }^{2}$, Dwi Agus Kurniawan ${ }^{3}$, Aziza Putri Ningsi ${ }^{4}$, Dinda Desma Romadona ${ }^{5}$, \\ Retno Wulan Dari ${ }^{6}$ \\ Universitas Jambi, Indonesia ${ }^{1,2,3,4,5,6}$ \\ darmaji@unja.ac.id'1 , astalinizakir@unja.ac.id ${ }^{2}$, dwiagus.k@unja.ac.id ${ }^{3}$, \\ azizap267@gmail.com ${ }^{4}$, ddromadhona@gmail.com ${ }^{5}$, wulan21789@gmail.com6
}

Received: June $14^{\text {th }}, 2020$. Revised: August $25^{\text {th }}, 2020$. Accepted: August 27 2020

Keywords :

Science Process Skills; Critical

Thinking Ability; Science;

Physics

\begin{abstract}
This study aims to look at the effect of science process skills on Jambi City Junior High School students' critical thinking ability on the density and reflection of the material in the mirror. This research method used was mixed method, while the design used was sequential explanatory. The study was conducted at Adhyaksa 1 Junior High School in Jambi City and Al-Jauharen Islamic junior high school in Jambi. The sampling technique used was cluster sampling, so that the sample of this study amounted to 58 students. The data collection instrument consisted of an observation sheet of science process skills, a test of critical thinking skills, and an interview. Data were analyzed using descriptive statistics and inferential statistics. Based on the results of the linear regression test that has been carried out, the $t$ value is greater than the t table, it can be said that there is a significant influence between science process skills and critical thinking skills on the density material and the reflection on the mirror. Students who have low process skills will tend to have low critical thinking skills. Low science process skills and students' thinking abilities lead to low student learning outcomes.
\end{abstract}

\section{INTRODUCTION}

Education is a process of improving the quality of life and obtaining and imparting the skills performed by students. This requires knowledge to be continuous developed under the times [1]. With education can improve the quality of self from each individual [2]. The purpose of education in Indonesia is to increase the resources of the faithful, pious, ethical, disciplined, responsible, and have high intellectual intelligence. In education in Indonesia itself, there are several levels; one of them is the High School level [3]. High school is the level of education that students must take before continuing to higher education. In high school education, studying various sciences, one of them is learning physical science.

Physics is a branch of natural science that discusses the symptoms and properties of objects in nature physically and formulated mathematically [4] [5]. States that physics is an experimental science 
Regression of Science Process Skills On Critical Thinking Skills In Two Junior High Schools In Jambi City Darmaji, Astalini, Dwi Agus Kurniawan, Aziza Putri Ningsi, Dinda Desma Romadona, Retno Wulan Dari

developed by physicists through experiments to prove a theory and also to improve and perfect it [6]. This is, as stated by Le Myers [7], "theoretical physicists use the results of experiments to refine their ideas and, at the same time, suggest new experiments." From some of the previous quotes, it can be concluded that physics is an experimental science that aims to prove the truth and perfect it. Therefore, to show the reality of a theory, it needs to be supported by practical activities. Practical activities will shape science process skills and critical thinking skills in students. Science process skills are skills that need to be installed in practice and are possess by students [8]. Science process skills are thinking skills that are us to create knowledge, solve problems, and formulate results [9]. Students' science process skills can be seen from practicum activities that lead to concepts in learning and applying science [10].

The skills that students must develop are science process skills. To form the students' Science Process Skills, they do practicum activities. Science process skills (SPS) are skills that are needed \& possessed by students to face a competition between people in the globalization era [11]. Science process skills are a set of complex abilities commonly used by scientists in conducting scientific investigations into a series of learning processes [12]. Science process skills are students' ability to apply scientific methods in understanding, developing \& discovering science [13]. Science process skills encourage students to find out for themselves facts, concepts of knowledge, and foster attitudes and values that are demand [14].

Science process skills are the abilities needed to acquire, develop, and apply concepts, principles, laws, and scientific theories in the form of mental, physical, and social skills [15]. Science process skills help students learn through knowledge to solve problems and find solutions [16]. Science process skills have two categories, basics science process skills and science process integration skills [17]. Process skills consist of basics skills, where these basics skills will be the basis for further skill development [18]. Basics science process skills include of observing, classifying, predicting, measuring, inferring, and communicating [19]. Integrated science process skills can be mastered after mastering the basics process skills. Integration science process skills include: identifying variables, making data tables, making graphs, describing relationships between variables, collecting and organizing data, analyzing experiments, forming hypotheses, defining variables operationally, designing experiments, conducting experiments [20]. So that science process skills can support students in developing critical thinking skills. According to Saido et al [21], KPS science process skills in learning can develop critical thinking skills among students; it can be seen in Figure 1.

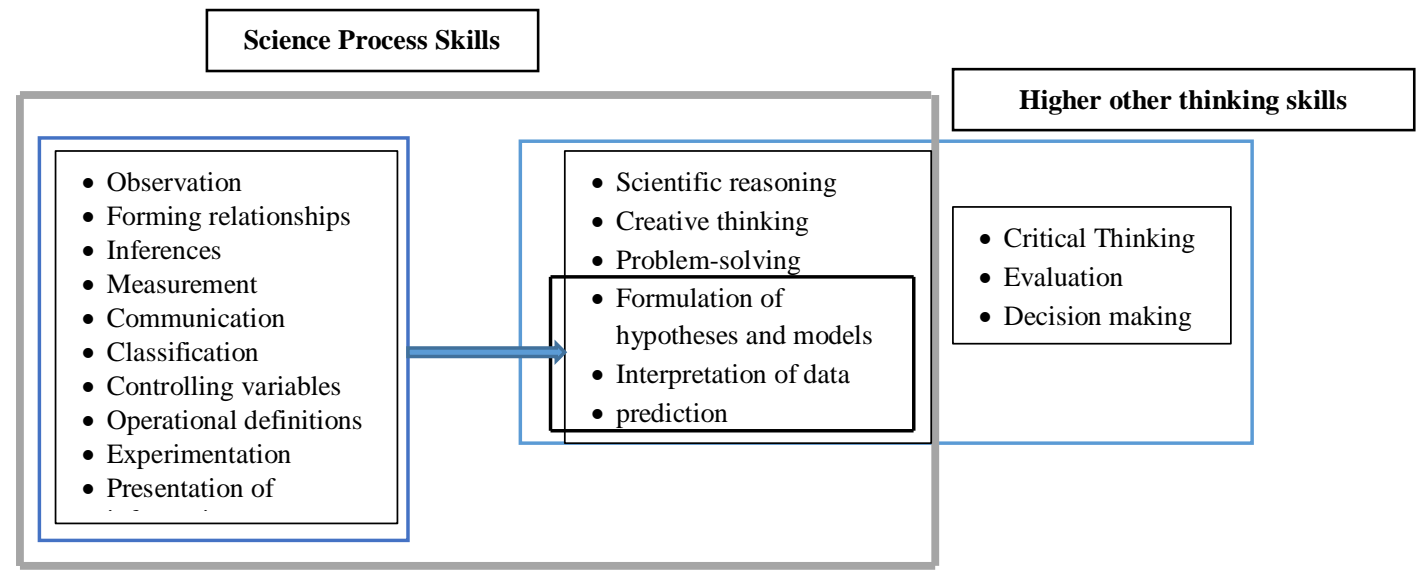

Fig 1. The relationship between science process skills and critical thinking skills in a scientific investigation

Critical thinking is part of high order thinking (higher-order thinking skills) [22]. Critical thinking is a crucial competency that must be possessed to solve the problems needed for individuals to live successfully and live responsibly and for society to face the challenges of the present and the future [23]. Critical thinking processes enable individuals to make reasonable judgments both in the classroom and 
in everyday life [24]. Critical thinking means students who are "able to think logically and sincerely, can find data and evaluate data systematically as a result of the learning process [25]. Critical thinking also trains students to think logically and not accept things easily.

According to Ennis [26], there are five indicators of critical thinking skills. Each index consists of subindicators that have a meaningful relationship with one another. The description of the signs and subindicators of critical thinking skills are as follows:

a. Elementary clarification, including: focusing questions, analyze arguments; ask questions, and answer clarifying questions or challenges.

b. The basis for making decisions or support (the basis for the resolution / essential support), including: considering the credibility of the source, make observations, and assess observation reports.

c. Inference (inference), including deduction and assess deduction; induction and assess induction; create and evaluate value statements.

d. Advanced clarification, including: defining terms and assessing definitions; identify assumptions.

e. Strategies and tactics (strategy and tactics), including determining actions; interact with other people.

Critical thinking aims to broaden the view (horizon) of students to support their ideals. Critical thinkers can find, understand, and evaluate statements that are logically and rationally relevant during the process of problem-solving or decision making [27]. The application of critical thinking skills in learning is vital, this is in line with opinions [28]. Critical thinking skills are learning methods or good ways that we must instill in the physics learning process.

Excellent critical thinking skills are essential for students to analyze thoughts and arguments and solve problems carefully [29]. To have excellent critical thinking skills, students must have critical thinking skills in general and specific aspects. The ability to think critically on particular issues is that students can understand the concepts learned. In contrast, students' general elements can solve problems and phenomena in daily life that require a correct understanding of physical concepts [30]. The lack of students' critical thinking skills can be caused by students who lack knowledge of learning concepts antheoriesals [31]. Misunderstanding the concept of learning can cause student learning outcomes to below [32]. Therefore it is vital for essential students' critical thinking skills in every physics learning material at school. Based on the explanation above, critical thinking can develop science process skills in students.

Based on the description above, the researcher will analyze the effect of science process skills on students' critical thinking skills in learning physics material density and reflections on mirrors at Adhyaksa 1 Junior High School in Jambi City and Al-Jauharen Islamic junior high school in Jambi. The purpose of this study was to see the effect of students' science process skills from two schools and two different materials in terms of the students' critical thinking abilities.

\section{METHOD}

The research method used is mixed methods (mixed methods), while the design used is sequential explanatory, which combines quantitative and qualitative research sequentially first using quantitative methods then qualitative methods [33]. The use of sequential illustrative design starts from collecting and analyzing quantitative data, followed by collecting and analyzing qualitative data [34]. In this method, quantitative data is preferred. Quantitative research emphasizes numerical assessment and is descriptive [35]. While the qualitative approach serves to prove, deepen, and expand quantitative data.

The research procedure carried out in this study is to analyze quantitative data first and then continue the quantitative data processing; it can be seen in Figure 2 below: 
Regression of Science Process Skills On Critical Thinking Skills In Two Junior High Schools In Jambi City Darmaji, Astalini, Dwi Agus Kurniawan, Aziza Putri Ningsi, Dinda Desma Romadona, Retno Wulan Dari

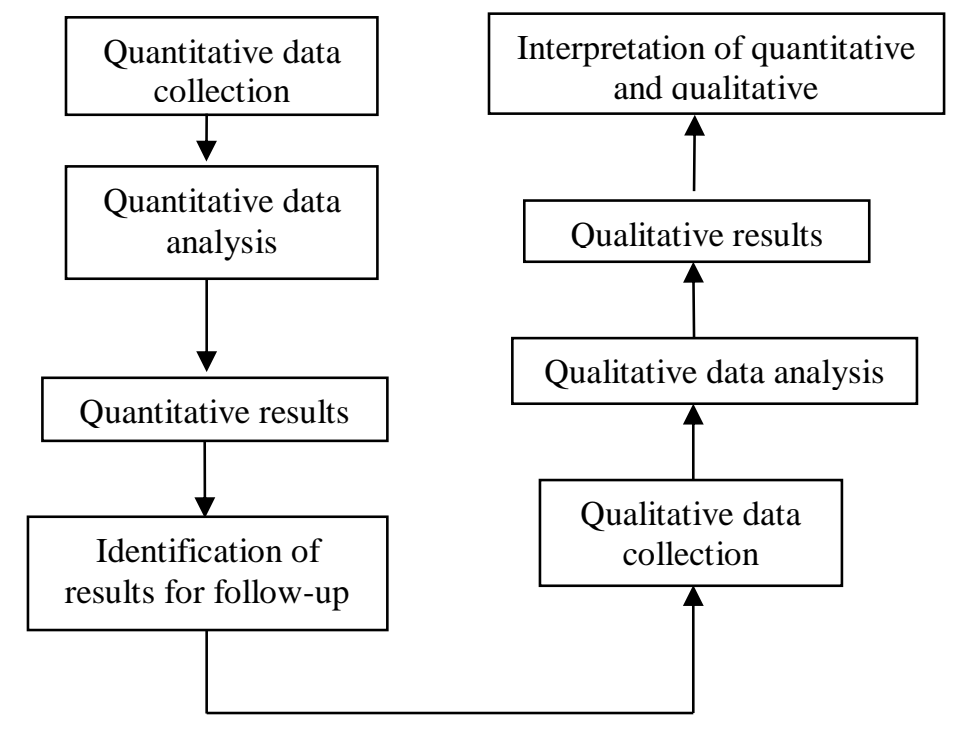

Fig 2. Research procedure

In this study, data collection techniques used science process skills observation sheets, critical thinking skills test questions, and interview sheets. The quantitative data collection technique uses the science process skills observation sheet using 16 indicators with 46 statements and the critical thinking skills test questions using five symbols with ten questions. Interviews were conducted with two students per class and to 2 teachers who taught physics material.

The sample used by the researcher was 58 students of class IX at Adhyaksa 1 Junior High School in Jambi City and Al-Jauharen Islamic junior high school in Jambi. The sampling technique in this study using cluster sampling. Cluster sampling (Area Sampling) is used to determine the sample if the object to be studied or the data source is comprehensive, for example, the population of a country, province, or district [33].

The instrument used in this study was the science process skills observation sheet, the critical thinking ability test questions that had been validated by expert validators. The things that were observed in this study were the process skills students had when doing practical activities in the laboratory and the ability to think critically after doing practicum activities. Ten observers assisted this observation. Percentages for each indicator sought were then stated in several categories; namely, the category Very Bad (VB), Bad (B), Good (G), Very Good (VG).

Data analysis was performed on quantitative data and qualitative data. This quantitative data analysis technique uses statistical analysis, namely, descriptive statistical analysis and inferential statistical analysis, which is carried out using the SPSS application. Descriptive statistical analysis, describes data from the average, maximum, and minimum values, to quickly obtain an overview of the characteristics of the object from the data. Meanwhile, inferential analysis for hypothesis testing by the following steps: 1) conducting prerequisite tests first in the form of normality test and linearity test;2) conducting a hypothesis test in the way of a Simple Linear Regression test; and 3) comparing t table with t count to conclude whether $\mathrm{H}_{\mathrm{o}}$ and $\mathrm{H}_{\mathrm{a}}$ are accepted or rejected. Meanwhile, interviews were conducted to obtain qualitative data to strengthen quantitative data.

\section{RESULTS AND DISCUSSIONS}

Below is a table of the research results on the influence of science process skills and critical thinking skills. 
JIPF, Vol. 5 No. 3, September 2020

Table 1. Analysis Results of the Description of Junior High School Students' Process Skills

\begin{tabular}{ccccccccc}
\hline Theory & Range & Category & Mean & Median & Min & Max & \% & f \\
\hline \multirow{5}{*}{ Density } & $46.00-80.50$ & VB & & & & & 41.4 & 24 \\
& $80.51-115.00$ & B & & & & & 19 & 11 \\
& $115.01-149.50$ & G & & 87.5 & 66 & 178 & 20.7 & 12 \\
& $149.51-184.00$ & VG & & & & & 19 & 11 \\
\hline \multirow{4}{*}{ Mirror } & $46.00-80.50$ & VB & & & & & 27.6 & 16 \\
Reflection & $80.51-115.00$ & B & & & & & 12.1 & 7 \\
& $115.01-149.50$ & G & 138.0 & 136.5 & 99 & 175 & 39.7 & 23 \\
& $149.51-184.00$ & VG & & & & & 20.7 & 12 \\
\hline
\end{tabular}

The description of the science process skills of junior high school students on density material and reflection on the mirror is presented in table 1. In this table, it can be seen that junior high school students' science process skills on density material are low because the highest percentage of $41.4 \%$ is in a naughty category. Simultaneously, the content on reflection on the mirror is classified as useful because the highest rate of $39.7 \%$ is in the first category. So the science process skills of students in each material are different.

Students' low science process skills are because students are rarely trained in discussion in learning subject matter or practicum [36]. Research by Darmaji et al [37] was aiming to improve students' process skills through practical activities that lead to student activeness in discovering new things. The root of the problem is that learning is dominated by teachers so that students act as learning objects. As a result, students lack the experience to develop science process skills [38]. This is in line with the interviews that researchers have conducted.

The low science process skills of students are because students are rarely trained in discussion in learning subject matter or practicum [36]. Research by Darmaji et al [37] was aiming to improve the process skills of students through practical activities that lead to student activeness in discovering new things. The root of the problem is that learning is dominated by teachers so that students act as learning objects. As a result, students lack the experience to develop science process skills [38]. This is in line with the interviews that researchers have conducted.

The researcher also conducted interviews with two students to see the students' science process skills. From the results of the meeting, it can be seen that, through the activity of the practice, it can be seen that the science process skills of junior high school students in each material are different. Because in general, they rarely carry out practical activities so that students do not explore science process skills. Not all students like practicum activities so that their abilities are different. Science process skills and critical thinking skills are closely related, because students who do not have the capabilities of the science process, the student's thinking will not be essential.

Table 2. Results of Analysis of Descriptions of Junior High School Students' Critical Thinking Skills

\begin{tabular}{ccccccccc}
\hline Theory & Range & Category & Mean & Median & Min & Max & \% & f \\
\hline \multirow{5}{*}{ Density } & $10.00-17.50$ & VB & & & & & 36.2 & 21 \\
& $17.51-25.00$ & B & \multirow{2}{*}{22.25} & 22 & \multirow{2}{*}{10} & 40 & 22.4 & 13 \\
& $25.01-32.50$ & G & & & & & 24.1 & 14 \\
& $32.51-40.00$ & VG & & & & & 17.2 & 10 \\
\hline \multirow{5}{*}{ Mirror Reflection } & $10.00-17.50$ & VB & & & & & 13.6 & 8 \\
& $17.51-25.00$ & B & \multirow{2}{*}{26.7} & 28.0 & \multirow{2}{*}{10} & 40 & 22.0 & 13 \\
& $25.01-32.50$ & G & & & & & 44.1 & 26 \\
& $32.51-40.00$ & VG & & & & & 20.3 & 12 \\
\hline
\end{tabular}


Regression of Science Process Skills On Critical Thinking Skills In Two Junior High Schools In Jambi City Darmaji, Astalini, Dwi Agus Kurniawan, Aziza Putri Ningsi, Dinda Desma Romadona, Retno Wulan Dari

From table 2, which comes from 58 respondents from junior high school students, the results of the analysis of students 'critical thinking skills on the density material found that students' critical thinking skills were classified as very low, this is said to be the highest percentage obtained by students of $36.2 \%$ which is in the deficient category. Whereas in the reflective material in the mirror, it is known that students' critical thinking skills are classified as useful, this is said to be the highest percentage obtained by students, which is $44.1 \%$, which is in the deficient category. The low ability of students to think critically is due, among other things, to the learning applied in schools which are still dominated by teachers so that they do not train students 'critical thinking skills and the students' low essential skills of thinking are because students are not used to getting questions with the C4-C6 cognitive level. The learning method used is also capable of critical thinking ability; not all students can be taught the same purpose.

Teachers still dominate physics learning; learning tends to memorize rather than develop thinking power so that students are weak in conveying their ideas, weak in analyzing, depending on others rather than being responsible for their own choices [39]. Science teaching in Indonesia mostly focuses on memorizing science concepts [40]. So the teacher must be able to create learning that trains students 'critical thinking skills. Training students' critical thinking skills that are done well will increase student interest in education and be confident in solving problems so that learning outcomes are maximized. So it is necessary to do better coaching to improve students' critical thinking skills [41]. So critical thinking is very important for students because of the ability to think critically. Students can improve physics learning outcomes in school and be able to develop science process skills [42].

Table 3. Test Results and Test Linear Normal Science Process Skills and Critical Thinking Skills

\begin{tabular}{ccc} 
Theory & $\begin{array}{c}\text { Kolmogorov-Smirnov } \\
\text { Sig. }\end{array}$ & Deviation from Linearity \\
& 0.274 & 0.268 \\
\hline Density & 0.507 & 0.692 \\
\hline
\end{tabular}

Data were analyzed to know the influence between two variables, named, the influenced between science process skills and students' critical thinking skills using simple linear regression tests, but before doing that, the normality and linearity tests were conducted. According to Sinaga et al [43], the normality test was used to determine whether the sample comes from a normally distributed population or not. There are several techniques used to test the normality of data, namely the Kolmogorov-Smirnov test. The linearity test is us to assess whether the specifications of the model used are correct or not [44]. Based on the results of the normality test on the material density obtained significance value $0.274>$ 0.05 , it can be concluded that the residual value is usually distributed. Based on the linearity test results, the significance value of deviation from linearity is known to be $0.268>0.05$, so it can be concluded that there is a linear relationship between science process skills and critical thinking abilities. While the normality test results on the reflecting material on the mirror obtained significance value $0.507>0.05$, it can be concluded that the residual value is usually distributed. Based on the results of the linearity test, the significance value of deviation from linearity is known to be $0.692>0.05$, so it can be concluded that there is a linear relationship between science process skills and critical thinking abilities. From the results of the normality and linearity test, it is known that the density and reflectance material in the mirror data is homogeneous and linear, so the Pearson correlation test will be performed to see the relationship between science process skills and critical thinking abilities. The analysis used to test the hypotheses in the study is the analysis/t-test, with the test criteria:

$H_{o}$ is accepted if $-t_{\text {table }} \leq t_{\text {arithmetic }} \geq t_{\text {table. }}$
$H_{0}$ is rejected if $t_{\text {arithmetic }}<t_{\text {table }}$ or $t_{\text {arithmetic }}>t_{\text {table }}$.

$t_{\text {table }}$ is sought at $\alpha=5 \%: 2=2.5 \%$ (2-tailed test) with degrees of freedom (df) $n-1$ or $58-1-1=56$ ( $\mathrm{n}$ is the number of cases/samples and $\mathrm{k}$ is the number independent variable). With $\mathrm{df}=56$, the results 
obtained for $\mathrm{t}$ table amounted to 2.0032. At the same time, $\mathrm{t}_{\text {arithmetic }}$ obtained from the results of simple linear regression analysis.

Table 4. Regression Analysis Science Process Skills and Critical Thinking Skills

\begin{tabular}{cccccc}
\multirow{2}{*}{ Theory } & \multicolumn{2}{c}{$\begin{array}{c}\text { Unstandardized } \\
\text { Coefficients }\end{array}$} & $\begin{array}{c}\text { Standardized } \\
\text { Coefficients }\end{array}$ & t & Sig. \\
\cline { 2 - 4 } & $\mathbf{B}$ & $\begin{array}{c}\text { Std. } \\
\text { Error }\end{array}$ & Beta & & \\
\hline \multirow{2}{*}{ Density } & 7.170 & 3.133 & & 2.288 & 0.026 \\
& 0.231 & .036 & 0.655 & 6.492 & 0.000 \\
Mirror Reflection & 10.417 & 2.719 & & 3.832 & 0.000 \\
& 0.053 & .023 & 0.296 & 2.320 & 0.024 \\
\hline
\end{tabular}

Based on table 4, the single linear regression analysis results on the material density can be seen that the $\mathrm{t}$ value is 6.492 . This value is much higher than $\mathrm{t}$ table, which is only 2.035 . Because $\mathrm{t}_{\text {arithmetic }}$ is more significant than $\mathrm{t}_{\text {table }}(6,492>2.0032), \mathrm{H}_{\mathrm{o}}$ is rejected. That is, there is a considerable influence on science process skills on students' critical thinking abilities. While in the reflective material on the mirror it can be seen that the $t$ value is 2,320 . This value is much greater than $t$ table which is only 2.035 . Because $t_{\text {arithmetic }}$ is greater than the $t_{\text {table }}(2,320>2.0032), H_{o}$ is rejected. That is, there is a significant influence on science process skills on students' critical thinking abilities. From the results of this analysis, it can be seen that there is a substantial influence between science process skills and the ability to think critically on the material density and reflection on the mirror.

Furthermore, the influence between science process skills and critical thinking skills on density material and reflection on the mirror in table 4. Based on the resulting significance value, it can be said that the relationship between science process skills and critical thinking skills on density material and reflection on the mirror is stable. So that if the students 'science process skills are low, the students' critical thinking skills are also small, and if the students 'science process skills are high, their critical thinking skills are too high. This is evident in this study that students have low process skills and little critical thinking skills. Based on the research conducted by Nugraha et al [23], it can be seen that science process skills have a strong relationship with critical thinking. Students with low science process skills have moderate or low critical thinking skills. Critical thinking skills are required to understand the concept well [45].

With this research, students become motivated to improve process skills and critical thinking skills through practical activities to become more active and more familiar with learning concepts and enhance student learning outcomes. With this research, the teacher knows learning techniques that can improve science process skills and students' critical thinking skills so that teachers can be more innovative and creative. The teacher can also find out the extent of science process skills and students' critical thinking skills through the practicum. This study's results can be used as input for the school to apply practical methods to improve students' science process skills and critical thinking skills. Also to improve the quality and function of schools as educational facilities and infrastructure.

\section{CONCLUSION AND SUGGESTION}

Science process skills and junior high school students' critical thinking skills in each material are different. It is necessary to train science process skills and students' critical thinking skills through student-centered learning and familiarize students with high-level education. This is because science process skills and students' critical thinking skills influence each other. Students who have low scientific processing skills will tend to have low essential abilities of thinking, and vice versa. 
Regression of Science Process Skills On Critical Thinking Skills In Two Junior High Schools In Jambi City Darmaji, Astalini, Dwi Agus Kurniawan, Aziza Putri Ningsi, Dinda Desma Romadona, Retno Wulan Dari

\section{REFERENCES}

[1] Astalini, A., Kurniawan, D. A., \& Putri, A. D. (2018). Identifikasi sikap implikasi sosial dari IPA, ketertarikan menambah waktu belajar IPA, dan ketertarikan berkarir dibidang IPA siswa SMP sekabupaten Muaro Jambi. Tarbiyah: Jurnal Ilmiah Kependidikan, 7(2).

[2] Triyanto, E., Anitah, S., \& Suryani, N. (2013). Peran kepemimpinan kepala sekolah dalam pemanfaatan media pembelajaran sebagai upaya peningkatan kualitas proses pembelajaran. Jurnal Teknologi Pendidikan, 1(2): 226-238.

[3] Astalini, A., Kurniawan, D. A., Perdana, R., \& Kurniasari, D. (2018). Identification of student attitudes toward physics learning at Batanghari District high school. The Educational Review, USA, 2(9): 475-484.

[4] Darmaji, D., Kurniawan, D. A., Astalini, A., \& Nasih, N. R. (2019). Persepsi Mahasiswa pada Penuntun Praktikum Fisika Dasar II Berbasis Mobile Learning. Jurnal Pendidikan: Teori, Penelitian, dan Pengembangan, 4(4): 516-523.

[5] Trisianawati, E., Djudin, T., \& Setiawan, R. (2016). Pengaruh model pembelajaran kooperatif tipe jigsaw terhadap hasil belajar siswa pada materi vektor di kelas X SMA Negeri 1 Sanggau Ledo. Jurnal Penelitian Fisika dan Aplikasinya (JPFA), 6(2): 51-60.

[6] Young, D. H., \& Freedman, R. A. (2002). Fisika Universitas. Jakarta: Erlangga.

[7] Le Myers, R. (2006). The Basic of Physics. London: Greenwood Press.

[8] Wahyuni, S., Indrawati, I., Sudarti, S., \& Suana, W. (2017). Developing science process skills and problem solving abilities based on outdoor learning in junior high school. Jurnal Pendidikan IPA Indonesia, 6(1).

[9] Aydın, A. (2013). Representation of science process skills in the chemistry curricula for grades 10, 11 and 12/Turkey. International Journal of Education and Practice, 1(5): 51-63.

[10] Karamustafaoğlu, S. (2011). Improving the science process skills ability of science student teachers using I diagrams. International Journal of Physics \& Chemistry Education, 3(1): 26-38.

[11] Budiyono, A., \& Hartini, H. (2016). Pengaruh Model Pembelajaran Inkuiri Terbimbing terhadap Keterampilan Proses Sains Siswa SMA. Wacana Didaktika, 4(2): 141-149.

[12] Manu, T. S. N., \& Nomleni, F. T. (2018). Pengaruh Metode Pembelajaran Karya Kelompok Terhadap Keterampilan Proses Sains Dengan Kovariabel Kemampuan Berpikir Kreatif Siswa Pada Mata Pelajaran Biologi. Scholaria: Jurnal Pendidikan dan Kebudayaan, 8(2): 167-179.

[13] Hutagalung, A. M. (2013). Efek Model Pembelajaran Inquiry Training Berbasis Media Komputer Terhadap Keterampilan Proses Sains Dan Kemampuan Berpikir Kritis Siswa (Doctoral dissertation, UNIMED).

[14] Wulanningsih, S., Prayitno, B. A., \& Probosar, R. (2012). Pengaruh model pembelajaran inkuiri terbimbing terhadap keterampilan proses sains ditinjau dari kemampuan akademik siswa SMA Negeri 5 Surakarta. Jurnal Pendidikan Biologi, 4(2): 33-43.

[15] Yuliati, Y. (2016). Peningkatan keterampilan proses sains siswa sekolah dasar melalui model pembelajaran berbasis masalah. Jurnal Cakrawala Pendas, 2(2).

[16] Darmaji, D., Kurniawan, D. A., Suryani, A., \& Lestari, A. (2018). An Identification of Physics PreService Teachers' Science Process Skills Through Science Process Skills-Based Practicum Guidebook. Jurnal Ilmiah Pendidikan Fisika Al-Biruni, 7(2): 239-245.

[17] Hırça, N. (2017). The influence of hands on physics experiments on scientific Process skills according to prospective teachers' experiences1. European Journal of Physics Education, 4(1): 614.

[18] Darmaji, D., Kurniawan, D. A., \& Lestari, A. (2018). Deskripsi keterampilan proses sains mahasiswa pendidikan fisika pada praktikum suhu dan kalor. Jurnal Riset dan Kajian Pendidikan Fisika, 5(2): 68-72.

[19] Raj, R. G., \& Devi, S. N. (2014). Science process skills and achievement in science among high school students. Scholarly Research Journal for Interdisciplinary Studies, 2(15): 2435-2443.

[20] Chabalengula, V. M., Mumba, F., \& Mbewe, S. (2012). How pre-service teachers' understand and perform science process skills. Eurasia journal of mathematics, science and technology education, 8(3): 167-176. 
[21] Saido, G. A. M., Siraj, S., Dewitt, D., \& Al-Amedy, O. S. (2018). Development of an instructional model for higher order thinking in science among secondary school students: a fuzzy Delphi approach. International Journal of Science Education, 40(8): 847-866.

[22] Klein, G. (2011). Critical thoughts about critical thinking. Theoretical Issues in Ergonomics Science, 12(3): 210-224.

[23] Nugraha, A. J., Suyitno, H., \& Susilaningsih, E. (2017). Analisis kemampuan berpikir kritis ditinjau dari keterampilan proses sains dan motivasi belajar melalui model pbl. Journal of Primary Education, 6(1): 35-43.

[24] Utami, B., Saputro, S., Ashadi, A., Masykuri, M., \& Widoretno, S. (2017). Critical thinking skills profile of high school students in learning chemistry. In International Journal of Science and Applied Science: Conference Series (Vol. 1, No. 2, pp. 124-130).

[25] Johan, H. (2013). Pengaruh SSCS problem solving untuk meningkatkan keterampilan berpikir kritis mahasiswa pada pembelajaran konsep listrik dinamis. Jurnal Pendidikan Matematika \& IPA, 4(1): 13-18.

[26] Ennis, R. H. (1985). A logical basis for measuring critical thinking skills. Educational leadership, 43(2): 44-48.

[27] Shaw, A., Liu, O. L., Gu, L., Kardonova, E., Chirikov, I., Li, G., ... \& Su, Q. (2019). Thinking critically about critical thinking: validating the Russian HEIghten ${ }^{\circledR}$ critical thinking assessment. Studies in Higher Education, 1-16.

[28] Syafitri, R., Asyhar, R., \& Asrial, A. (2016). Pengaruh Model Inquiry Training dan Berpikir Kritis Terhadap Kemampuan Berpikir Ilmiah Mahasiswa pada Mata Kuliah Kimia Dasar. Edu-Sains: Jurnal Pendidikan Matematika dan Ilmu Pengetahuan Alam, 5(1).

[29] Ritdamaya, D., \& Suhandi, A. (2016). Konstruksi instrumen tes keterampilan berpikir kritis terkait materi suhu dan kalor. Jurnal Penelitian \& Pengembangan Pendidikan Fisika, 2(2): 87-96.

[30] Tiruneh, D. T., De Cock, M., Weldeslassie, A. G., Elen, J., \& Janssen, R. (2017). Measuring critical thinking in physics: Development and validation of a critical thinking test in electricity and magnetism. International Journal of Science and Mathematics Education, 15(4): 663-682.

[31] Sundari, P. D., Parno, P., \& Kusairi, S. (2018). Students'critical Thinking Ability In Integrated Learning Model. Jurnal Kependidikan: Penelitian Inovasi Pembelajaran, 2(2): 348-360.

[32] Aminudin, A. H., Rusdiana, D., Samsudin, A., Hasanah, L., \& Maknun, J. (2019, November). Measuring critical thinking skills of 11th grade students on temperature and heat. In Journal of Physics: Conference Series (Vol. 1280, No. 5, p. 052062). IOP Publishing.

[33] Sugiyono. (2016). Statistika untuk Penelitian. Bandung: Alfabeta.

[34] Creswell, J. W. (2013). Research design pendekatan kualitatif, kuantitatif, dan mixed. Yogyakarta: Pustaka Pelajar.

[35] Machmud, M. (2005). Tuntunan Penulisan Tugas Akhir Berdasarkan Prinsip Dasar Penelitian Ilmiah. Jakarta: Erlangga.

[36] Özgelen, S. (2012). Students' science process skills within a cognitive domain framework. Eurasia Journal of Mathematics, Science and Technology Education, 8(4): 283-292.

[37] Kurniawan, D. A., Lumbantoruan, A., \& Samosir, S. C. (2019). Mobile Learning in Higher Education for The Industrial Revolution 4.0: Perception and Response of Physics Practicum. International Journal of Interactive Mobile Technologies, 13(9).

[38] Ningsih, D. U., Santosa, S., \& Sugiharto, B. (2011). Penerapan Strategi Pembelajaran think talk write Berbasis Kontekstual untuk Meningkatkan Keterampilan Proses Sains Siswa Kelas x-8 SMA Negeri 1 Sukoharjo Tahun Pelajaran 2010/2011. Jurnal Pendidikan Biologi, 3(2): 55-64.

[39] Muhlisin, A., Susilo, H., Amin, M., \& Rohman, F. (2016, June). Improving critical thinking skills of college students through RMS model for learning basic concepts in science. In Asia-Pacific Forum on Science Learning and Teaching (Vol. 17, No. 1, p. 12). The Education University of Hong Kong, Department of Science and Environmental Studies.

[40] Prayitno, B. A., Corebima, D., Susilo, H., Zubaidah, S., \& Ramli, M. (2017). Closing the science process skills gap between students with high and low level academic achievement. Journal of Baltic Science Education, 16(2): 266.

[41] Çavdar, G., \& Doe, S. (2012). Learning through writing: Teaching critical thinking skills in writing assignments. PS: Political Science \& Politics, 45(2): 298-306.

[42] Husein, S., Herayanti, L., \& Gunawan, G. (2017). Pengaruh penggunaan multimedia interaktif 
Regression of Science Process Skills On Critical Thinking Skills In Two Junior High Schools In Jambi City Darmaji, Astalini, Dwi Agus Kurniawan, Aziza Putri Ningsi, Dinda Desma Romadona, Retno Wulan Dari

terhadap penguasaan konsep dan keterampilan berpikir kritis siswa pada materi suhu dan kalor. Jurnal Pendidikan Fisika dan Teknologi, 1(3): 221-225.

[43] Sinaga, E. K., Matondang, Z., \& Sitompul, H. (2009). Statistika: Teori dan Aplikasi Pada Pendidikan. Jakarta: Yasasan Kita Menulis.

[44] Jubilee, E. (2014). SPSS untuk Pemula. Jakarta: PT. Gramedia.

[45] Puspita, A. R., Paidi, P., \& Nurcahyo, H. (2017). Analisis Keterampilan Proses Sains LKPD Sel di SMA Negeri Kota Bekasi. Pend. Biologi-S1, 6(3): 164-170. 